\title{
Characterization of a bacteriocin as biopreservative synthesized by indigenous lactic acid bacteria from dadih soya traditional product used in West Sumatra, Indonesia
}

\author{
ENDAH RETNANINGRUM ${ }^{1, \bullet}$, TANIA YOSSI ${ }^{1}$, RINI NUR'AZIZAH ${ }^{1}$, FADILLA SAPALINA $^{2}$, \\ PERISKILA DINA KALI KULLA ${ }^{2}$ \\ ${ }^{1}$ Faculty of Biology, Universitas Gadjah Mada. Jl. Teknika Selatan, Sekip Utara, Sleman 55281, Yogyakarta, Indonesia. Tel./fax. +62-274-580839, \\ Fax.: +62-274-6492355, `email: endahr@ugm.ac.id \\ ${ }^{2}$ Graduate Program, Faculty of Biology, Universitas Gadjah Mada. Jl. Teknika Selatan, Sekip Utara, Sleman 55281, Yogyakarta, Indonesia
}

Manuscript received: 9 June 2020. Revision accepted: 20 August 2020.

\begin{abstract}
Retnaningrum E, Yossi T, Nur'azizah R, Sapalina F, Kulla PDK. 2020. Characterization of a bacteriocin as biopreservative synthesized by indigenous lactic acid bacteria from dadih soya traditional product used in West Sumatra, Indonesia. Biodiversitas 21: 4192-4198. A total of 4 isolates of lactic acid bacteria (strain BDL08, BDL11, BDL12, and BDL13) isolated from dadih soya were investigated for the ability to produce bacteriocin based on their antibacterial activities against Listeria monocytogenes ATCC 7644. Based on comparative 16S rDNA sequencing analysis, isolates BDL 11, BDL12, and BDL13 were identified as Lactobacillus plantarum while the isolates BDL 08 was identified as Leuconostoc mesenteroides. All crude bacteriocins producing strains revealed broad antibacterial spectrum against 7 different indicator bacteria, including Gram-positive and Gram-negative bacteria. L. plantarum BDL11 displayed the highest bacteriocin activity relative to others. The bacteriocin produced by the strain was not affected by $\mathrm{pH}, \mathrm{heating}$, and $\mathrm{NaCl}$ concentration but was sensitive to proteolytic enzymes. This research indicated that the bacteriocin in the food industry has the potential to be used as a biopreservative.
\end{abstract}

Keywords: 16S rDNA, antibacterial activities, food industry, Lactobacillus plantarum, proteolytic enzyme

\section{INTRODUCTION}

Dadih soya is an Indonesian traditional milk fermentation product that replaced soya milk as a substrate. This product is mainly consumed by people living in West Sumatera, Indonesia. During fermentation process, soya milk is poured into a bamboo tube capped with banana leaves. It is then fermented spontaneously at room temperature for 48 hours by indigenous lactic acid bacteria derived from both of soya milk and bamboo tube. Generally, two species of bamboo, Gombong bamboo (Gigantochloa verticilata) and Ampel bamboo (Bambusa vulgaris) are used in this fermentation process.

Lactic acid bacteria contain group of bacteria which play role in the dadih soya fermentation. During this fermentation process, the bacteria can reduce $\mathrm{pH}$ value by producing lactic acid. This lactic acid can inhibit undesirable contamination of microorganisms in the product. In addition, these bacteria may produce metabolites such as diacetyl, hydrogen peroxide, some enzymes, antibiotics, reuterin, and bacteriocins (Mazzoli et al. 2014; Fernández-Cruz et al. 2016; Yépez et al. 2017). This bacteria group is characterized as Gram-positive, nonspore-forming cocci, coccobacilli or rods, low $\mathrm{G}+\mathrm{C}$ content, and non-motile. These bacteria are also characterized by their capability to ferment sugar into lactic acid, catalase-negative, and oxidase-negative (Nguyen et al. 2013; Gänzle et al. 2015; Renschler et al. 2020).
Bacteriocins have been the subject of particular interest among the metabolites developed by LAB because of their potential advantages in applying them as natural food biopreservatives (Field 2018; Juturu et al. 2018; Kumariya et al. 2019). These bacteriocins are antimicrobials that are ribosomally synthesized, releasing bioactive peptides or peptide complexes with bactericidal or bacteriostatic effects (Singh et al. 2015; Zou et al. 2018).

The advantages of bacteriocins produced by LAB in food preservation have been reported by several researchers. Their properties, including nontoxic to eukaryotic cells, have little influence on the gut microbiota and $\mathrm{pH}$, heat tolerant, have a wide antimicrobial spectrum against many pathogenic food-borne spoilage bacteria and are capable of being bactericidal has attracted number of researchers to investigate this group of bacteria (Yi et al. 2016; Barman et al. 2018). This leads a way to carry out the research to identify LAB producing bacteriocin isolated from dadih soya-based on $16 \mathrm{~S}$ rDNA gene as molecular marker and to characterize the bacteriocins which would be used as biopreservatives in food products.

\section{MATERIALS AND METHODS}

\section{Sampling and isolation of LAB}

Samples (dadih soya fermentation) were collected from traditional market in West Sumatera, Indonesia. A $25 \mathrm{~g}$ of each sample was added to $225 \mathrm{~mL}$ of sterile buffered 
peptone water, homogenized in a stomacher for 2 min and serial dilutions were plated onto De Man, Rogosa Sharpe (MRS) Agar (Merck). Plates were incubated under microaerophilic conditions at $30^{\circ} \mathrm{C}$ for $72 \mathrm{~h}$. Isolates were purified by repeated streaking onto the respective growth media. All isolates were tested for morphological and biochemical properties such as Gram-reaction, sporeformation, motility, catalase, and oxidase production. The Gram-positive, catalase-negative, and oxidase-negative isolates were selected as lactic acid bacteria and further analyzed.

\section{Screening of bacteriocin producing LAB strains}

The strains were screened for bacteriocin production by analyzing antimicrobial activity against indicator pathogenic bacteria (Listeria monocytogenes ATCC 7644) using agar well diffusion assay (Pasteris et al. 2014; An et al. 2015). The isolates bacteria which showed an inhibition zone diameter against Listeria monocytogenes ATCC 7644 were selected for further investigation.

\section{Genotypic identification by 16S rDNA gene sequencing}

All isolates producing bacteriocins were identified using 16S rDNA gene sequencing. The genomic DNA of each strain was directly isolated from overnight liquid culture using DNA extraction kit (MOBIO protocol) and used as template for PCR reaction. The DNA was then amplified by polymerase chain reaction (PCR) using primers designed to amplify $1500 \mathrm{bp}$ fragment of the $16 \mathrm{~S}$ rDNA region. The primer used was $27 \mathrm{~F}$ (5'AGAGTTTGATCMTGGCTCAG-3') and 1492R (5'CCGTCAATTCMTTTRAGTTT-3'). The amplification was performed using Eppendorf Gradient thermocycler with initial denaturation $95^{\circ} \mathrm{C}(2 \mathrm{~min}), 35$ cycles at denaturation $95^{\circ} \mathrm{C}(1 \mathrm{~min})$, annealing $55^{\circ} \mathrm{C}(1 \mathrm{~min})$, extension $72^{\circ} \mathrm{C}(1 \mathrm{~min})$. Finally with extension of $72^{\circ} \mathrm{C}(10$ min). Sequencing was performed using enzymatic chain terminator technique, developed by (Sanger et al. 1977), by using a PRISM BigDye Terminator v3.1 cycle sequencing kit and then analyzed by ABI Prism 3730XL DNA Analyser (Applied Biosystems, CA, USA). The sequences were BLAST in the GenBank database (www. ncbi.nhm.nih.gov) for species assignment. The phylogenetic tree was constructed by the Neighbor-Joining method (Saitou and Nei 1987), based on the Kimura 2parameter model (Kimura, 1980) with bootstrap analysis (1000 replications) using the software MEGA (version 7) (Kumar et al. 2016).

\section{Antimicrobial spectrum of bacteriocin producing isolates}

The selected LAB isolates were tested against pathogenic microorganisms listed in Table 1. Crude bacteriocins were prepared and analyzed by the agar well diffusion assay. Previously the cell-free supernatants (CFS) as crude bacteriocin was prepared and obtained by centrifugation of culture at $10,000 \mathrm{~g}, 20 \mathrm{~min}$, and at $4^{\circ} \mathrm{C}$. These supernatant collections were then neutralized to $\mathrm{pH}$ 7.0 with $3 \mathrm{M} \mathrm{NaOH}$ for the complete inactivation of organic acids, which might be produced by the strains. In addition, inhibitory activity of hydrogen peroxide might also be produced by the strains that were eliminated by the addition of catalase of $1 \mathrm{mg} / \mathrm{mL}$ catalase (Sigma, St. Louis, USA). Therefore, the CFS samples were not related to the production of either organic acids or hydrogen peroxide, confirmed as crude bacteriocin. The crude bacteriocin obtained then subjected to filter sterilization $(0.22 \mu \mathrm{m})$.

All samples were examined using the agar well diffusion assay for their antimicrobial activity. One hundred $\mu \mathrm{L}$ of each pathogenic bacteria indicator $\left(10^{6}\right.$ $\mathrm{CFU} / \mathrm{mL}$ ) listed in Table 1 . was spread on the nutrient agar plates. Previously, all pathogens were grown with nutrient broth (NB) medium under aerobic conditions at $37{ }^{\circ} \mathrm{C}$. Equidistant wells ( $4 \mathrm{~mm}$ diameter) were formed by boring the nutrient agar plate with corer borer. Those wells then were filled with $80 \mathrm{~mL}$ of crude bacteriocin and incubated at $37^{\circ} \mathrm{C}$ for $24 \mathrm{~h}$. The antimicrobial activity of those bacteriocins was measured and expressed as $\mathrm{AU}\left(\mathrm{mm}^{2} /\right.$ $\mathrm{mL}$ ), which is the unit area of inhibition zone per unit volume. Therefore, the antimicrobial activity was calculated using the following equation.

\section{Antimicrobial activity $(\mathrm{AU})=\mathrm{Lz}-\mathrm{Ls} / \mathrm{V}$}

Where: LZ is clear zone area $\left(\mathrm{mm}^{2}\right)$, LS is well area $\left(\mathrm{mm}^{2}\right)$, and $\mathrm{V}$ is volume of sample $(\mathrm{mL})$ (Abbasiliasi et al. 2012).

\section{Characterization of the crude bacteriocin stability to $\mathrm{pH}$, temperature, $\mathrm{NaCl}$ concentrations, and proteolytic enzymes}

The sensitivity of crude bacteriocins produced by selected isolate to $\mathrm{pH}$ was investigated by adjusting $\mathrm{pH}$ of crude bacteriocins from $\mathrm{pH} 2$ to 10 and incubated at $37{ }^{\circ} \mathrm{C}$ for $4 \mathrm{~h}$. To analyze effects of temperature, $\mathrm{NaCl}$ concentrations, and proteolytic enzymes, the crude bacteriocins were adjusted previously to $\mathrm{pH} 7.0$ by $3 \mathrm{M}$ $\mathrm{HCl}$ or $\mathrm{NaOH}$. Effects of temperature were investigated at $60^{\circ} \mathrm{C}, 80{ }^{\circ} \mathrm{C}$, and $100{ }^{\circ} \mathrm{C}$ for $30 \mathrm{~min}$. Effect of of $\mathrm{NaCl}$ on crude bacteriocins were also observed at $\mathrm{NaCl}$ concentrations of $1.0 \%, 2.0 \%, 3.0 \%, 4.0 \%$ and $5.0 \%$. Proteolytic enzymes that used to analyze of bacteriocins stabilities were trypsin (1000 - 2000 units/mg solid, SigmaAldrich, St. Louis, MO, USA), a-chymotrypsin $(\geq 40$ units/mg; Sigma-Aldrich, St. Louis, MO, USA) and proteinase K $(20 \mathrm{mg} / \mathrm{mL}$; TaKaRa Bio Inc., Otsu, Shiga, Japan). Then, all samples were assayed against the indicator strain Listeria monocytogenes ATCC 7644 using the agar well diffusion assay as described above.

Table 1. Pathogenic microorganisms used in the antimicrobial spectrum test for selected $\mathrm{LAB}$ producing bacteriocin

\begin{tabular}{lll}
\hline \multicolumn{1}{c}{ Strains } & \multicolumn{1}{c}{ Origin } & Growth conditions \\
\hline Streptococcus mutans & ATCC 25175 & Nutrient broth, $37{ }^{\circ} \mathrm{C}$ \\
Staphylococcus aureus & ATCC 29213 & Nutrient broth, $37{ }^{\circ} \mathrm{C}$ \\
Bacillus cereus & ATCC 11778 & Nutrient broth, $37{ }^{\circ} \mathrm{C}$ \\
Pseudomonas aeruginosa & ATCC 27853 & Nutrient broth, $37{ }^{\circ} \mathrm{C}$ \\
Escherichia coli & ATCC 25922 & Nutrient broth, $37{ }^{\circ} \mathrm{C}$ \\
Salmonella typhi & ATCC 6539 & Nutrient broth, $37{ }^{\circ} \mathrm{C}$ \\
\hline
\end{tabular}




\section{Statistical analysis}

The experiments were done in triplicates. All data are shown as means \pm standard deviation. Mean data of treatments were compared by the analysis of variance (oneway ANOVA) followed by Duncan Multiple Range Test (DMRT) approach for the measurement of mean differences. Differences at $\mathrm{p}<0.05$ were considered significant.

\section{RESULTS AND DISCUSSION}

\section{Lactic acid bacteria producing bacteriocin isolated from dadih soya}

Total of 55 bacteria cultures was obtained in the MRSA medium as a result of isolation in this research. Those isolates of lactic acid bacteria (LAB) group were selected based on morphological and biochemical properties. Ten strains (BDL01, BDL05, BDL08, BDL09, BDL11, BDL12, BDL13, BDL15, BDL18, BDL20 strain) clearly showed characteristics as Gram-positive, rods shape, non-sporeforming, non-motile, catalase, and oxidative negative. Therefore, $10 \mathrm{LAB}$ isolates were further screened for their producing bacteriocin ability.

Previously, researches reported that bacteriocins could inhibit foodborne pathogenic bacteria, $L$. monocytogenes. This pathogen showed high virulence and resistance even though grew at stressful condition, such as high salt levels, freezing, drying, $\mathrm{pH}$ levels and heat processes (Changcheng et al. 2017; Huang et al. 2019). Therefore, it is difficult to control in food products. Its species has been found to contaminate several food products, such as smoked salmon, dairy product, cheese, pasta, fruit and vegetable (Vitas et al. 2014; Fei et al. 2016; de Cesare et al. 2018; Hamidiyan et al. 2018; Haubert et al. 2018; Hiko et al. 2019; Huang et al. 2019). In addition, L. monocytogenes were used successfully as indicator strains to screen bacteriocin-producing LAB isolates (Tan et al. 2014; Md Sidek et al. 2016; Wong et al. 2017).

Therefore, for screening the ability of LABs producing bacteriocin, ten strains originating from Indonesian fermented food "dadih soya" were assayed for their antimicrobial activity and potential bacteriocin production against L. monocytogenes ATCC 19115 using well diffusion method. Table 2 demonstrated that among 10 strains, 4 isolates $(40 \%)$ exhibited inhibitory activities against this indicator bacteria. These isolates displaying an inhibition zone greater than $3 \mathrm{~mm}$. The Inhibition zone diameters observed at strain BDL 8, BDL 11, BDL 12, and BDL 13 were $8 \mathrm{~mm}, 5 \mathrm{~mm}, 3 \mathrm{~mm}$, and $6 \mathrm{~mm}$, respectively.

\section{Genotypic identification LAB producing bacteriocin}

The rapid identification of $\mathrm{LAB}$ has been determined by primers and probes targeting the 16S rDNA spacer regions (Balca'zar et al. 2007; Yu et al. 2015; Michel et al. 2016). This 16S rDNA gene of the selected strain was amplified by PCR, by which a 1500 bp gene fragment was sequenced and submitted to Genbank. The Blast search performed against GenBank revealed a large number of similar $16 \mathrm{~S}$ rDNA gene sequences. The BLAST results of most promising bacterial isolates showed $>99 \%$ similarities between available GenBank entries as displayed in Table 3, the strain BDL8 was clearly identified Leuconostoc mesenteroides, whereas others (BDL11, BDL 12 and BDL13 strains) were identified as Lactobacillus plantarum. In addition, a neighbor-joining phylogenetic tree based on $16 \mathrm{~S}$ rDNA sequences of BDL8, BDL 11, BDL 12, and BDL 13 strains were constructed with other closely related species of $L$. mesenteroides and $L$. plantarum obtained from NCBI (Figure 1). This phylogenetic analysis revealed that the strains BDL11, BDL12, and BDL 13 were clustered together with $L$. plantarum, strain BDL8 with $L$. mesenteroides which are completely separated from Pseudomonas husainii as an outgroup by 1000 bootstrap values.

In comparison with previous studies carried out by researches, both of $L$. plantarum and $L$. mesenteroides have been isolated from fermented products, (Choi et al. 2015; Oguntoyinbo and Narbad 2015; Berbegal et al. 2016; Du et al. 2018; Jimenez et al. 2018; Lee and Kim 2019; Nurhikmayani et al. 2019). Moreover, L. plantarum has also reported from digestive tracts of shrimp (Kongnum et al. 2012), human breast milk (Jiang et al. 2016) and Italian rye-grass (Vijayakumar et al. 2015), whereas, genus of Leuconostoc mesenteroides mainly isolated from meat products (Kaihei et al. 2011) and Oreochromis niloticus (Paray et al. 2018).

\section{Antimicrobial spectrum activity of crude bacteriocins}

The antimicrobial spectrum measurements of crude bacteriocin produced by 4 strains were displayed in Table 4. The indicator microorganisms for its analysis include Gram-positive bacteria (S. mutans, S aureus, B. subtilis) and Gram-negative bacteria ( $P$. aeruginosa, E. coli, $S$. typhi). All crude bacteriocins showed bacteriocin activities against all indicator microorganisms tested, but the values of activity varied among the strains.

Table 2. Inhibition zone diameter of LAB isolates against Listeria monocytogenes using agar well diffusion assay

\begin{tabular}{ll}
\hline Strain & Inhibition zone diameter $(\mathbf{m m})$ \\
\hline BDL01 & 0 \\
BDL05 & 0 \\
BDL08 & $3 \pm 0.01$ \\
BDL09 & 0 \\
BDL11 & $8 \pm 0.02$ \\
BDL12 & $5 \pm 0.01$ \\
BDL13 & $6 \pm 0.02$ \\
BDL15 & 0 \\
BDL18 & 0 \\
BDL20 & 0 \\
\hline
\end{tabular}

Note: Mean values $(n=3)$ for each experiment. 
Table 3. Genotypic identification LAB producing bacteriocin

\begin{tabular}{cclccc}
\hline OTU & Strain & \multicolumn{1}{c}{ Species of LAB homolog } & Identity $(\%)$ & Accession number & Base pairs \\
\hline 1 & BDL08 & $\begin{array}{l}\text { Leuconostoc mesenteroides strain ATCC 8293 } \\
\text { Leuconostoc p seudomesenteroides strain NRIC 1777 }\end{array}$ & 99.50 & NR_040814.1 \\
& & Lactobacillus plantarum strain CIP 103151 & 99.59 & NR_074957.1 & $1,448 \mathrm{bp}$ \\
2 & BDL11 & NR_104573.1 & $1,527 \mathrm{bp}$ \\
& & Lactobacillus plantarum strain NRRL B-14768 & 99.32 & NR_042394.1 & 1474 bp \\
3 & \multirow{2}{*}{ BDL12 } & Lactobacillus plantarum strain CIP 103151 & 99.52 & NR_104573.1 & $1,527 \mathrm{bp}$ \\
& & Lactobacillus plantarum strain JCM 1149 & 99.35 & NR_117813.1 & $1466 \mathrm{bp}$ \\
4 & \multirow{2}{*}{ BDL13 } & Lactobacillus plantarum strain CIP 103151 & 99.48 & NR_104573.1 & $1,527 \mathrm{bp}$ \\
& & Lactobacillus plantarum strain JCM 1149 & 99.30 & NR_117813.1 & 1466 bp \\
\hline
\end{tabular}

Table 4. The antimicrobial spectrum crude bacteriocin of isolates against 7 different microorganism indicators.

\begin{tabular}{lcccc}
\hline \multirow{2}{*}{ Indicator microorganisms } & \multicolumn{3}{c}{ Bacteriocin activity (AU/mL) } \\
\cline { 2 - 5 } & $\begin{array}{c}\text { L. plantarum } \\
\text { BDL11 }\end{array}$ & $\begin{array}{c}\text { L. plantarum } \\
\text { BDL12 }\end{array}$ & $\begin{array}{c}\text { L. plantarum } \\
\text { BDL13 }\end{array}$ & $\begin{array}{c}\text { L. mesenteroides } \\
\text { BDL008 }\end{array}$ \\
\hline Streptococcus mutans ATCC 25175 & 40 & 30 & 35 & 25 \\
Staphylococcus aureus ATCC 29213 & 38 & 25 & 34 & 20 \\
Bacillus cereus ATCC 11778 & 38 & 15 & 25 & 10 \\
Pseudomonas aeruginosa ATCC 27853 & 25 & 10 & 15 & 7 \\
Escherichia coli ATCC 25922 & 20 & 10 & 10 & 10 \\
Salmonella typhi ATCC 6539 & 18 & 8 & 8 & 5 \\
\hline
\end{tabular}

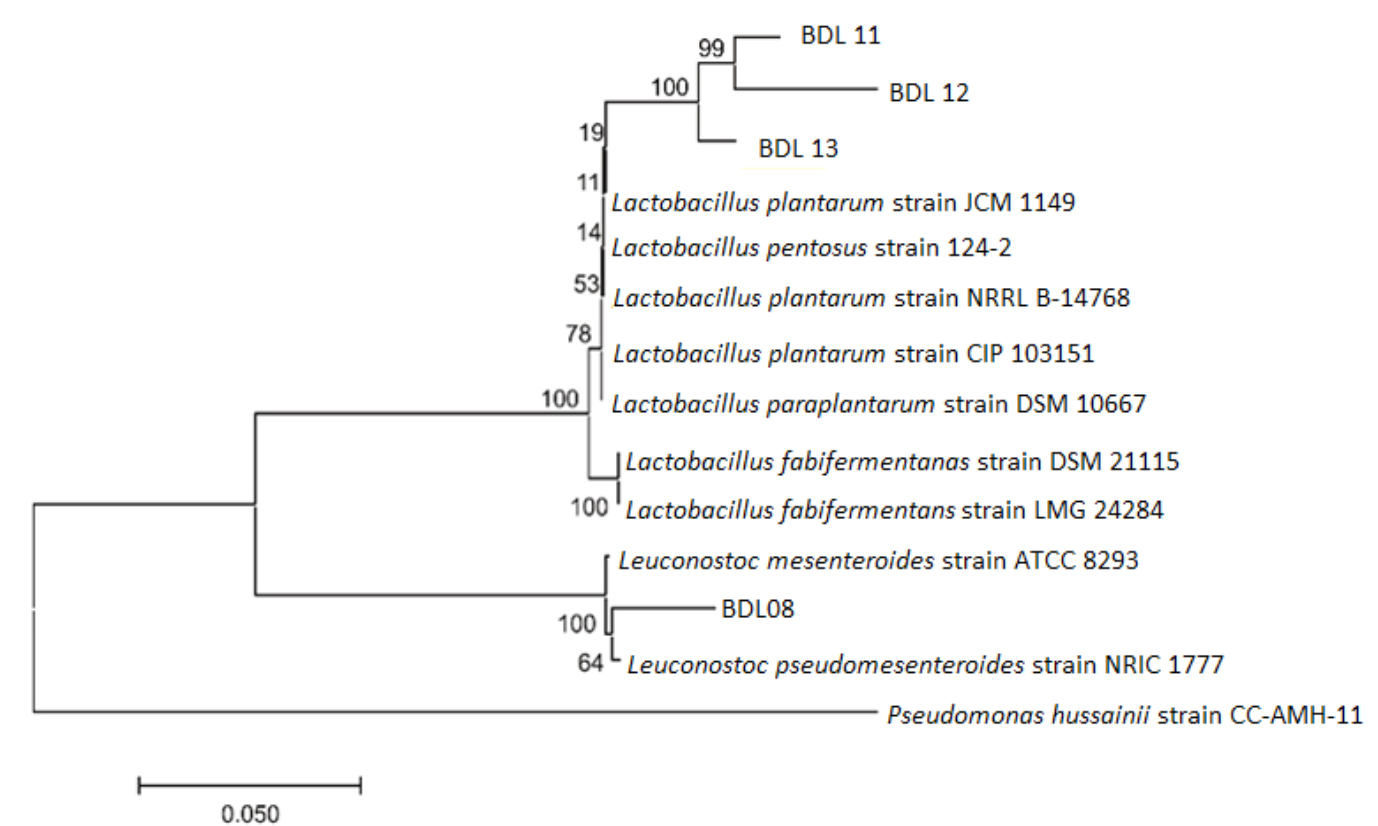

Figure 1. Phylogenetic tree developed using 16S rDNA gene sequences which are available in the GenBank database, using the method Neighbor-joining with bootstrap of 1000 replication

From the observations, it was found that crude bacteriocin activities were lower against Gram-negative bacteria compared with Gram-positive bacteria. This result was similar to previous research reported by $\mathrm{Xi}$ et al. (2018) who observed the Enterococcus faecalis TG2. The bacteriocins activity analyses were measured in the range of 25-40 AU/mL and 5-25 AU/mL against Gram-positive and Gram-negative bacteria, respectively. The pathogenic bacterium $\mathrm{S}$. mutans was most sensitive to those crude bacteriocins LABs, whereas $S$. typhi was most resistant. The result of this sensitivity test was similar to previous studies (Kawada-Matsuo and Komatsuzawa 2017; Kim et al. 2019). The strongest crude bacteriocin activity to all indicators was observed in L. plantarum BDL11, whereas, the weakest it was observed in L. mesenteroides BDL008. Therefore, the crude bacteriocin characters of L. plantarum BDL11 were further analyzed their stabilities.

Generally, bacteriocins from lactic acid bacteria were regarded to have no antibacterial activity against Gramnegative bacteria (Kang and Lee 2005, Drider et al. 2006; Powell et al. 2007). This phenomenon was caused the lack of cell wall lipoteichoic acid on the Gram-negative bacterial surface (Ahn et al. 2017). However, these crude bacteriocins produced by 4 LAB isolates also had an 
inhibitory effect on three Gram-negative bacteria, including E. coli ATCC 25922, B. cereus ATCC 11778, and S. typhi ATCC 6539. Similar reports have shown that some bacteriocins produced by LAB, could inhibit both Grampositive and Gram-negative bacteria. The bacteriocins LXA produced by Lactobacillus coryniformis XN8 has been reported to have antibacterial activity against Grampositive bacteria ( $S$. aureus, Enterococcus sakazakii) and Gram-negative bacteria (E. coli, Salmonella sp) (Yi et al. 2016). Bacteriocin produced by L. plantarum SJ33 has also been reported to inhibit the growth of Gram-positive bacteria ( $S$. aureus, Aeromonas hydrophila, Clostridium perfringens, Clostridium sporogenes, B. subtilis, B. cereus) and Gram-negative bacteria (E. coli, Vibrio parahaemolyticus, Proteus vulgaris, Klebsiella pneumonia, P. aeruginosa) (Mohapatra and Jeevaratnam 2019).

\section{Characteristics of the crude bacteriocins of 4 isolates}

The stability of the crude bacteriocin characters obtained from L. plantarum BDL11 against several treatments was summarised in Table 5. The activity of crude bacteriocin strain remained active in the range of $\mathrm{pH}$ values of 2-10. There was high bacteriocin activity at $\mathrm{pH} 2$, and lower activity at $\mathrm{pH} 8$ and 10. In addition, heat treatment up to $100^{\circ} \mathrm{C}$ for $30 \mathrm{~min}$ did not affect the stability of crude bacteriocin. Similarly, treatment of $\mathrm{NaCl}$ concentrations did not affect the bacteriocin activities. These results were in accordance with previous studies on bacteriocins of Lactobacillus sakei GM3 (Avaiyarasi et al. 2016), Lactobacillus fermentum BZ532 (Rasheed et al. 2020) and Lactobacillus plantarum SLG10 (Pei et al. 2020). Those stability characters of the crude bacteriocin especially for $\mathrm{pH}$, heat, and $\mathrm{NaCl}$ treatments were useful for being applied as biopreservative agents to control pathogens and spoiling bacteria in food products (Yang et al. 2014; Ahmad et al. 2017). In addition, its antibacterial activity was inactivated by proteolytic enzymes (trypsin, chymotrypsin, and proteinase K), indicating it is proteinaceous in nature (Mohapatra and Jeevaratnam 2019).

Table 5. The antibacterial activity of the crude bacteriocin obtained from L. plantarum BDL11 against several treatments

\begin{tabular}{lcc}
\hline Treatments & & $\begin{array}{c}\text { Antibacterial activity } \\
\text { (AU/mL) }\end{array}$ \\
\hline Control & 7 & 65 \\
$\mathrm{pH}$ & 2 & 120 \\
& 4 & 65 \\
& 6 & 32 \\
Temperature & 8 & 25 \\
& 10 & 25 \\
$\mathrm{NaCl}$ & $60^{\circ} \mathrm{C}$ & 65 \\
& $80^{\circ} \mathrm{C}$ & 33 \\
& $100^{\circ} \mathrm{C}$ & 33.5 \\
& $1.0 \%$ & 65 \\
Proteolytic enzymes & $2.0 \%$ & 57.8 \\
& $3.0 \%$ & 57.5 \\
& $4.0 \%$ & 57.5 \\
& $5.0 \%$ & 57.3 \\
& Trypsin & 0 \\
& Chymotrypsin & 0 \\
& Proteinase K & 0 \\
\hline
\end{tabular}

Application of biopreservatives to inhibit spoilage bacteria as well as pathogenic bacteria in food products have been previously reported by several researchers (da Silva Sabo et al. 2017; del Castillo-Santaella et al. 2018; Ho et al. 2018; Skariyachan and Govindarajan 2019). These biopreservatives can increase food shelf-life and avoid cases of foodborne diseases. Some of the bacteria that cause foodborne diseases were detected in food products including $S$. mutans, S. aureus, P. aeruginosa, E. coli, B. cereus and S. typhi (Gabriel et al. 2017; Bundidamornet et. al. 2018; Gnanasekaran et al. 2019; Incili et al. 2019). In comparison with synthetic preservatives such as benzoic acid, tertiary-butyl hydroquinone (TBHQ), formalin, butylated hydroxytoluene (BHT), and butylated hydroxyanisole (BHA), the biopreservatives were found safer for human use because they did not form mutagenic compounds that caused cancer (Li et al. 2017; Piper and Piper 2017; Dehghan et al. 2018; Mohamed et al. 2018; Mohammadzadeh-Aghdash et al. 2018; Abd-Elhakim et al. 2020). Whereas, the food products are generally preserved using a combination of biopreservation and other treatments, including $\mathrm{pH}$, heat, and $\mathrm{NaCl}$. From the investigations, the crude bacteriocin produced by the strain has several unique characteristics that were stable in those treatments.

Based on the investigation results, it can be concluded that the crude bacteriocin-producing BDL11 strain which isolated from traditional Indonesian fermented product (dadih soya) had highest bacteriocin activity. In addition, this strain was identified as L. plantarum on the basis of $16 \mathrm{~S}$ rDNA gene sequence. Its crude bacteriocin had broad antibacterial activities against both Gram-positive and Gram-negative bacteria, stable in several treatments of temperature, $\mathrm{pH}$, and $\mathrm{NaCl}$. These findings indicate that crude bacteriocin L. plantarum BDL11 could be used as a potentially effective and natural food biopreservative. More research is needed to understand the metabolism and production of bacteriocin using low-cost medium for industrial food production.

\section{ACKNOWLEDGEMENTS}

This research was supported by RTA UGM 2020 (Contract No: 2488/UN1.P.III/DIT-LIT/PT/2020)

\section{REFERENCES}

Abbasiliasi S, Joo Shun T, Ibrahim TAT, Ramanan RN, Vakhshiteh F, Mustafa S, Ling TC, Rahim RA, Arif AB. 2012. Isolation of Pediococcus acidilactici $\mathrm{Kp} 10$ with ability to secrete bacteriocin-like inhibitory substance from milk products for applications in food industry. BMC Microbiol 12 (1): 260. DOI: 10.1186/1471-2180-12260.

Abd-Elhakim YM, Hashem MMM, Abo-EL-Sooud K, Ali HA, Anwar A, El-Metwally AE, Mahmoud EA, Moustafa GG. 2020. Involvement of tumor necrosis factor- $\alpha$, interferon-gamma- $\gamma$, and interleukins $1 \beta, 6$, and 10 in immunosuppression due to long-term exposure to five common food preservatives in rats. Gene 7425: 144590. DOI: 10.1016/j.gene.2020.144590.

Ahmad V, Khan MS, Jamal QMS, Alzohairy MA, Al Karaawi MA, Siddiqu MU. 2017. Antimicrobial potential of bacteriocins: In 
therapy, agriculture and food preservation. Intl J Antimicrob Agents 49 (1): 1-11. DOI: 10.1016/j.ijantimicag.2016.08.016.

Ahn H, Kim J, Kim WJ. 2017. Isolation and characterization of bacteriocin producing Pediococcus acidilactici HW01 from malt and its potential to control beer spoilage lactic acid bacteria. Food Control 80: 59-66. DOI: 10.1016/j.foodcont.2017.04.022

An J, Zhu W, Liu Y, Zhang X, Sun L, Hong P, Wang Y, Xu C, Xu D, Liu H. 2015. Purification and characterization of a novel bacteriocin CAMT2 produced by Bacillus amyloliquefaciens isolated from marine fish Epinephelus areolatus. Food Control 51: 278-282. DOI: 10.1016/j.foodcont.2014.11.038.

Avaiyarasi ND, Ravindran AD, Venkatesh P, Arul V. 2016. In vitro selection, characterization and cytotoxic effect of bacteriocin of Lactobacillus sakei GM3 isolated from goat milk. Food Control 69: 124-133. DOI: 10.1016/j.foodcont.2016.04.036.

Balca'zar J, de Blas I, Ruiz-Zarzuela I, Vendrell D, Girone's O, Muzquiz JL. 2007. Sequencing of variable regions of the 16S rRNA gene for identification of lactic acid bacteria isolated from the intestinal microbiota of healthy salmonids. Comp Immunol Microbiol Infect Dis 30 (2): 111-118. DOI: $10.1016 /$ j.cimid.2006.12.001

Barman S, Ghosh R, Mandal NC. 2018. Production optimization of broadspectrum bacteriocin of three strains of Lactococcus lactis isolated from homemade buttermilk. Ann Agrar Sci 16 (3): 286-296. DOI: 10.1016/j.aasci.2018.05.004

Berbegal C, Pena N, Russo P, Grieco F, Pardo I, Ferrer S, Spano G, Capozzi V. 2016. Technological properties of Lactobacillus plantarum strains isolated from grape must fermentation. Food Microbiol 57: 187-194. DOI: 10.1016/j.fm.2016.03.002

Bundidamorn D, Supawasit W, Trevanich S. 2018. A new single-tube platform of melting temperature curve analysis based on multiplex real-time PCR using EvaGreen for simultaneous screening detection of Shiga toxin-producing Escherichia coli, Salmonella spp. and Listeria monocytogenes in food. Food Control 94: 195-204. DOI: 10.1016/j.foodcont.2018.07.001

Changcheng L, Huang L, Hwang C. 2017. Effect of temperature and salt on thermal inactivation of Listeria monocytogenes in salmon roe. Food Control 73 (B): 406-410.

Choi EA, Chang HC. 2015. Cholesterol-lowering effects of a putative probiotic strain Lactobacillus plantarum EM isolated from kimchi LWT - Food Sci Technol 62 (1): 210-217. DOI 10.1016/j.lwt.2015.01.019.

da Silva Sabo S, Pérez-Rodríguez N, Domínguez JM, de Souza Oliveira RP. 2017. Inhibitory substances production by Lactobacillus plantarum ST16Pa cultured in hydrolyzed cheese whey supplemented with soybean flour and their antimicrobial efficiency as biopreservatives on fresh chicken meat. Food Res Intl 99 (1): 762 769. DOI: $10.1016 /$ j.foodres.2017.05.026.

de Cesare A, Vitali S, Tessema GT, Trevisani M, Fagereng TM, Beaufort A, Manfreda G, Skjerdal T. 2018. Modelling the growth kinetics of Listeria monocytogenes in pasta salads at different storage temperatures and packaging conditions. Food Microbiol 76: 154-163. DOI: 10.1016/j.fm.2018.04.013.

del Castillo-Santaella T, Cebrián R, Maqueda M, Gálvez-Ruiz MJ, Maldonado-Valderrama J. 2018. Assessing in vitro digestibility of food biopreservative AS-48. Food Chem 246: 249-257. DOI: 10.1016/j.foodchem.2017.10.149.

Dehghan P, Mohammadi A, Mohammadzadeh-Aghdash H, Dolatabadi JEN. 2018. Pharmacokinetic and toxicological aspects of potassium sorbate food additive and its constituents. Trends Food Sci Tech 80: 123-130. DOI: 10.1016/j.tifs.2018.07.012.

Drider D, Fimland G, Héchard Y, McMullen LM, Prévost H. 2006. The continuing story of class IIa bacteriocins. Microbiol Mol Biol Rev 70 (2): 564-582. DOI: 10.1128/MMBR.00016-05.

Du R, Zhao F, Pan L, Han Y, Xiao H, Zhou Z. 2018. Optimization and purification of glucan sucrase produced by Leuconostoc mesenteroides DRP2-19 isolated from Chinese Sauerkraut. Prep $\begin{array}{lllll}\text { Biochem } & \text { Biotech } 48 & \text { (6): } 465-473 . & \text { DOI: }\end{array}$ 10.1080/10826068.2018.1466149.

Fei YS, Wei W, Li B, Jie HY, Ping DY, Jin X, Qin LF. 2016. Antimicrobial resistance, virulence profile, and molecular characterization of Listeria monocytogenes isolated from ready-to-eat food in China, 2013-2014. Biomed Environ Sci 29 (6): 448-452. DOI: $10.3967 / \mathrm{bes} 2016.058$.

Fernández-Cruz ML, Martín-Cabrejas I, Pérez-del Palacio J, Gaya P, Díaz-Navarro C, Navas JM, Arqués JL. 2016. In vitro toxicity of reuterin, a potential food biopreservative. Food Chem Toxicol 96: 155-159.

Field D, Ross RP, Hill C. 2018. Developing bacteriocins of lactic acid bacteria into next-generation biopreservatives. Curr Opin Food Sci 20: 1-6. DOI: 10.1016/j.cofs.2018.02.004

Gabriel AA, Vera DD, Lazo Omy, Azarcon VB, de Ocampo CG, Marasigan JC, Sandel GT. 2017. Ultraviolet-C inactivation of Escherichia coli $\mathrm{O} 157: \mathrm{H7}$, Listeria monocytogenes, Pseudomonas aeruginosa, and Salmonella enteritica in liquid egg white. Food Control 73 (B): 1303-1309. DOI: 10.1016/j.foodcont.2016.10.060

Gänzle MG. 2015. Lactic metabolism revisited: Metabolism of lactic acid bacteria in food fermentations and food spoilage. Curr Opin Food Sci 2: 106-117. DOI: 10.1016/j.cofs.2015.03.001

Gnanasekaran G, Lee JH, Kim H, Cho SH. 2019. The complete genome sequence and comparative genome analysis of the multi-drug resistant food-borne pathogen Bacillus cereus. Genomics S0888-7543 (19): 30079-5. DOI: 10.1016/j.ygeno.2019.05.003.

Hamidiyan N, Salehi-Abargouei A, Rezaei Z, Dehghani-Tafti R, AkramiMohajeri F. 2018. The prevalence of Listeria spp. food contamination in Iran: A systematic review and meta-analysis. Food Res Intl 107: 437-450. DOI: 10.1016/j.foodres.2018.02.038.

Haubert L, dos Santos Cruxen CE, Fiorentini AM, Padilha da Silva WP. 2018. Tetracycline resistance transfer from foodborne Listeria monocytogenes to Enterococcus faecalis in Minas Frescal cheese. Intl Dairy J 87: 11-15. DOI: 10.1016/j.idairyj.2018.07.014.

Hiko A, Bushura E, Belina D. 2019. Occurrence of Listeria in food chilling facilities of the different campuses in Haramaya University, Ethiopia. Sci Afr 3: e00074. DOI: 10.1016/j.sciaf.2019.e00074.

Ho VTT, Lo R, Bansal N, Turner MS. 2018. Characterisation of Lactococcus lactis isolates from herbs, fruits and vegetables for use as biopreservatives against Listeria monocytogenes in cheese. Food Control 85: 472-483. DOI: 10.1016/j.foodcont.2017.09.036.

Huang J, Luo Y, Zhou B, Zheng J, Nou X. 2019. Growth and survival of Salmonella enterica and Listeria monocytogenes on fresh-cut produce and their juice extracts: Impacts and interactions of food matrices and temperature abuse conditions. Food Control 100: 300-304. DOI: 10.1016/j.foodcont.2018.12.035

Incili GK, Koluman A, Aktüre A, Ataşalan A. 2019. Validation and verification of LAMP, ISO, and VIDAS UP methods for detection of Escherichia coli $\mathrm{O} 157: \mathrm{H7}$ in different food matrices. J Microbiol Methods 165: 105697. DOI: 10.1016/j.mimet.2019.105697.

Jiang M, Zhang F, Wan C, Xiong Y, Shah NP, Wei H, Tao, X. 2016. Evaluation of probiotic properties of Lactobacillus plantarum WLPL04 isolated from human breast milk. J Dairy Sci 99 (3): 17361746. DOI: $10.3168 /$ jds.2015-10434.

Jimenez E, Alba Yepez A, Perez-Cataluna A, Vasquez, ER, Davila DZ, Vignolo G, Aznar R. 2018. Exploring diversity and biotechnological potential of lactic acid bacteria from tocosh-traditional Peruvian fermented potatoes - by high throughput sequencing (HTS) and culturing. LWT 87: 567-574. DOI: 10.1016/j.lwt.2017.09.033

Juturu V, Wu JC. 2018. Microbial production of bacteriocins: Latest research development and applications. Biotechnol Adv 36 (8): 21872200. DOI: 10.1016/j.biotechadv.2018.10.007.

Kaihei Oki K, Rai AK, Sato S, Watanabe K, Tamang JP. 2011. Lactic acid bacteria isolated from ethnic preserved meat products of the Western Himalayas. Food Microbiol 28 (7): 1308-1315. DOI: 10.1016/j.fm.2011.06.001.

Kang JH, Lee MS. 2005. Characterization of a bacteriocin produced by Enterococcus faecium GM-1 isolated from an infant. J Appl Microbiol $98 \quad$ (5): $1169-1176 . \quad$ DOI: $10.1111 /$ j.13652672.2005.02556.x

Kawada-Matsuo M, Komatsuzawa H. 2017. Role of Streptococcus mutans two-component systems in antimicrobial peptide resistance in the oral cavity. Jpn Dent Sci Rev 53 (3): 86-94. DOI: 10.1016/j.jdsr.2016.12.002.

Kim N, Kim WJ, Kang S. 2019. Anti-biofilm effect of crude bacteriocin derived from Lactobacillus brevis DF01 on Escherichia coli and Salmonella typhimurium. Food Control 98: 274-280. DOI: 10.1016/j.foodcont.2018.11.004

Kimura M. 1980. A simple method for estimating evolutionary rates of base substitutions through comparative studies of nucleotide sequences. J Mol Evol 16: 111-120. DOI: 10.1007/BF01731581.

Kongnum K, Hongpattarakere T. 2012. Effect of Lactobacillus plantarum isolated from digestive tract of wild shrimp on growth and survival of white shrimp (Litopenaeus vannamei) challenged with Vibrio harveyi. 
Fish Shellfish Immun 32 (1): 170-177. DOI: 10.1016/j.fsi.2011.11.008.

Kumar S, Stecher G, Tamura K. 2016. MEGA7: Molecular evolutionary genetics analysis version 7.0 for bigger datasets. Mol Biol Evol 33: 1870-1874. DOI: 10.1093/molbev/msw054.

Kumariya R, Garsa AK, Rajput YS, Sood SK, Akhtar N, Patel S. 2019. Bacteriocins: Classification, synthesis, mechanism of action and resistance development in food spoilage causing bacteria. Microb Pathog 128: 171-177.

Lee S, Kim M. 2019. Leuconostoc mesenteroides MKSR isolated from kimchi possesses $\alpha$-glucosidase inhibitory activity, antioxidant activity, and cholesterol-lowering effects. LWT 116: 108570. DOI 10.1016/j.lwt.2019.108570.

Li J, Bi Y, Sun S, Peng D. 2017. Simultaneous analysis of tertbutylhydroquinone, tert-butylquinone, butylated hydroxytoluene, 2 tert-butyl-4-hydroxyanisole, 3-tert-butyl-4-hydroxyanisole, $\alpha$ tocopherol, $\gamma$-tocopherol, and $\delta$-tocopherol in edible oils by normalphase high-performance liquid chromatography. Food Chem 234: 205-211. DOI: 10.1016/j.foodchem.2017.04.176.

Mazzoli R, Bosco F, Mizrahi I, Bayer EA, Pessione E. 2014. Towards lactic acid bacteria-based biorefineries. Biotechnol Adv 32 (7): 12161236. DOI: 10.1016/j.biotechadv.2014.07.005.

Md Sidek NL, Tan JS, Abbasiliasi S, Wong FWF, Mustafa S, Ariff AB. 2016. Aqueous two-phase flotation for primary recovery of bacteriocin-like inhibitory substance (BLIS) from Pediococcus acidilactici Kp10. J Chromatogr B 1027: 81-87. DOI: 10.1016/j.jchromb.2016.05.024.

Michel E, Monfort C, Deffrasnes M, Guezenec S, Lhomme E, Barret M, Sicard D, Dousset X, Onno B. 2016. Characterization of relative abundance of lactic acid bacteria species in French organic sourdough by cultural, qPCR and MiSeq high-throughput sequencing methods. Intl J Food Microbiol 239: 35-43. DOI: 10.1016/j.ijfoodmicro.2016.07.034.

Mohamed TY, Nassar MY, Amin AS, Elnadi MM. 2018. Spectrophotometric determination of butylated hydroxyanisole in pure form and cream formulation via an oxidation-reduction reaction. Chemical Data Collections 15-16: 229-237. DOI: 10.1016/j.cdc.2018.05.002

Mohammadzadeh-Aghdash H, Sohrabi Y, Mohammadi A, Shanehband D, Dehghan P, Dolatabadi JEN. 2018. Safety assessment of sodium acetate, sodium diacetate and potassium sorbate food additives. Food Chem 257: 211-215. DOI: 10.1016/j.foodchem.2018.03.020.

Mohapatra AR, Jeevaratnam K. 2019. Inhibiting bacterial colonization on catheters: Antibacterial and antibiofilm activities of bacteriocins from Lactobacillus plantarum SJ33. J Glob Antimicrob Resist 19: 85-92. DOI: 10.1016/j.jgar.2019.02.021.

Nguyen DTL, Hoorde, KV, Cnockaert M, De Brandt E, De Bruyne K, Thanh Le B, Vandamme P. 2013. A culture-dependent and independent approach for the identification of lactic acid bacteria associated with the production of nem chua, a Vietnamese fermented meat product. Food Res Intl 50 (1): 232-240.

Nurhikmayani R, Daryono BS, Retnaningrum E. 2019. Isolation and molecular identification of antimicrobial-producing Lactic Acic Bacteria from chao, South Sulawesi (Indonesia) fermented fish $\begin{array}{llll}\text { product. } & \text { Biodiversitas } 20 & \text { (4): 1063-1068. DOI }\end{array}$ 10.13057/biodiv/d200418

Oguntoyinbo FA, Narbad A. 2015. Multifunctional properties of Lactobacillus plantarum strains isolated from fermented cereal foods. J Funct Foods 17: 621-631. DOI: 10.1016/j.jff.2015.06.022.

Paray BA, Rather IA, Al-Sadoon MK, Hamad AF. 2018. Pharmaceutical significance of Leuconostoc mesenteroides KS-TN11 isolated from Nile Tilapia, Oreochromis niloticus. Saudi Pharm J 26 (4): 509-514. DOI: $10.1016 /$ j.jsps.2018.02.006

Pasteris SE, Pingitore VE, Ale CE, Nader-Maias ME, 2014 Characterization of a bacteriocin produced by Lactococcus lactis subsp. lactis CRL 1584 isolated from a Lithobates catesbeianus hatchery. World J Microbiol Biotechnol 30 (3): 1053-1062. DOI: 10.1007/s11274-013-1524-9.

Pei J, Jin W, Abd El-Aty AM, Baranenko DA, Gou X, Zhang H, Geng J, Jiang L, Chen D, Yue T. 2020. Isolation, purification, and structural identification of a new bacteriocin made by Lactobacillus plantarum found in conventional kombucha. Food Control 110: 106923. DOI: 10.1016/j.foodcont.2019.106923
Piper JD, Piper PW. 2017. Benzoate and sorbate salts: a systematic review of the potential hazards of these invaluable preservatives and the expanding spectrum of clinical uses for sodium benzoate. Compr Re Food Sci F 16 (5): 868-880. DOI: 10.1111/1541-4337.12284.

Powell JE, Witthuhn RC, Todorov SD, Lmt D. 2007. Characterization of bacteriocin ST8KF produced by a kefir isolate Lactobacillus plantarum ST8KF. Intl Dairy J 17 (3): 190-198. DOI: 10.1016/j.idairyj.2006.02.012

Rasheed HA, Tuoheti T, Zhang Y, Azi F, Tekliye M, Dong M. 2020. Purification and partial characterization of a novel bacteriocin produced by bacteriocinogenic Lactobacillus fermentum BZ532 isolated from Chinese fermented cereal beverage (Bozai). LWT 124: 109113. DOI: 10.1016/j.1wt.2020.109113.

Renschler MA, Wyatt A, Anene N, Robinson-Hill R, Pickerill ES, Fox NE, Griffith JA, McKillip JL. 2020. Using nitrous acid-modified de Man, Rogosa, and Sharpe medium to selectively isolate and culture lactic acid bacteria from dairy foods. J Dairy Sci 103 (2): 1215-1222. DOI: $10.3168 /$ jds.2019-17041

Saitou N, Nei M. 1987. The neighbor-joining method: A new method for reconstructing phylogenetic trees. Mol Biol Evol 4 (4): 406-4025.

Sanger F, Nicklen S, Coulson AR. 1977. DNA sequencing with chainterminating inhibitors. Proc Natl Acad Sci USA 4 (12): 5463-5467.

Singh NP, Tiwari A, Bansal A. Thakur S, Sharma G, Gabrani R. 2015. Genome level analysis of bacteriocins of lactic acid bacteria. Comput Biol Chem 56: 1-6. DOI: 10.1016/j.compbiolchem.2015.02.013.

Skariyachan S, Govindarajan S. 2019. Biopreservation potential of antimicrobial protein-producing Pediococcus spp. towards selected food samples in comparison with chemical preservatives. Intl J Food Microbiol 29116: 189-196. DOI: 10.1016/j.ijfoodmicro.2018.12.002.

Tan JS, Abbasiliasi S, Ibrahim TAT, Kadkhodaei S, Suan $\mathrm{Ng} \mathrm{H}$, Vakhshiteh F, Ajdari Z, Mustafa S, Ling TC, Rahim RA, Ariff AB. 2014. Primary recovery of thermostable lipase 42 derived from recombinant Escherichia coli BL21 in aqueous two-phase flotation. Sep Pur Technol 133: 328-334. DOI: 10.1016/j.seppur.2014.06.048.

Vijayakumar M, Ilavenil S, Kim DH, Arasu MV, Priya K, Choi KC. 2015. In-vitro assessment of the probiotic potential of Lactobacillus plantarum KCC-24 isolated from Italian rye-grass (Lolium multiflorum) forage. Anaerobe 32: 90-97. DOI: 10.1016/j.anaerobe.2015.01.003.

Vitas AI, Díez-Leturia M, Tabar L, González D. 2014. Improving the methodology for Listeria monocytogenes detection in smoked salmon by using the wet pooling test. Intl J Food Microbiol 184: 109-112. DOI: 10.1016/j.ijfoodmicro.2013.11.036.

Wong FWF, Ariff AB, Abbasiliasi S, Stuckey DC. 2017. Recovery of a bacteriocin-like inhibitory substance from Pediococcus acidilactici Kp10 using surfactant precipitation. Food Chem 232: 245-252. DOI: 10.1016/j.foodchem.2017.03.102

Xi Q W, Wang J, Du RP, Zhao FK, Han Y, Zhou ZJ. 2018. Purification and characterization of bacteriocin produced by a strain of Enterococcus faecalis TG2. Appl Biochem Biotech 184 (4): 11061119. DOI: $10.1007 / \mathrm{s} 12010-017-2614-1$.

Yang SC, Lin CH, Sung CT, Fang JY. 2014. Antibacterial activities of bacteriocins: Application in foods and pharmaceuticals. Front Microbiol 5 (241): 1-10. DOI: 10.3389/fmicb.2014.00241

Yépez A, Luz C, Meca G, Vignolo G, Mañes J, Aznar R. 2017. Biopreservation potential of lactic acid bacteria from Andean fermented food of vegetal origin. Food Control 78: 393-400. DOI: 10.1016/j.foodcont.2017.03.009

Yi L, Dang J, Zhang L, Wu Y, Liu B, Lü X. 2016. Purification, characterization and bactericidal mechanism of a broad spectrum bacteriocin with antimicrobial activity against multi drug resistant strains produced by Lactobacillus coryniformis XN8. Food Control 67: 53-62. DOI: 10.1016/j.foodcont.2016.02.008.

Yu J, Wang HM, Zha MS, Qing YT, Bai N, Ren Y, Xi X, Liu WJ, Menghe BLG, Zhang HP. 2015. Molecular identification and quantification of lactic acid bacteria in traditional fermented dairy foods of Russia. J Dairy Sci 98 (8): 5143-5154. DOI: 10.3168/jds.2015-9460

Zou J, Jiang H, Cheng H, Fang J, Huang G. 2018. Strategies for screening, purification and characterization of bacteriocins. Intl J Biol Macromol 117: 781-789. DOI: 10.1016/j.ijbiomac.2018.05.233 